\title{
The Effect of Vacuum Impregnation Pretreatment on Air-Drying Kinetics of Pears
}

\author{
Şeyma Uysal ${ }^{1, a}$, Fikret Pazır ${ }^{1, b, *}$ \\ ${ }^{1}$ Engineering Faculty, Food Engineering Department, Ege University, 35040 Izmir, Turkey, \\ *Corresponding author
}

\begin{tabular}{|c|c|}
\hline A R T I C L E I N F O & A B S T R A C T \\
\hline $\begin{array}{l}\text { Keywords: } \\
\text { Vacuum Pretreatment } \\
\text { Drying } \\
\text { Drying Time }\end{array}$ & $\begin{array}{l}\text { The aim of this study was to examine the drying kinetics of pears (Pyrus communis L.) with and } \\
\text { without vacuum impregnation and under the different temperature by using tray dryer. Vacuum } \\
\text { impregnation were applied to the the pears }(15 \mathrm{~mm} \text { thickness, } 65 \mathrm{~mm} \text { outer and } 20 \mathrm{~mm} \text { inner } \\
\text { dimensions respectively) with the conditions of } 50^{\circ} \text { Brix impregnation solution concentration, } 225 \\
\text { mbar vacuum pressure and } 45 \text { min vacuum time. Drying process was carried out at temperatures of } \\
55,65 \text { and } 75^{\circ} \mathrm{C} \text {. Drying time of non-vacuum impregnated pears was determined } 640,500 \text { and } 340 \\
\text { min and vacuum impregnated pears was determined } 700,540 \text { and } 560 \text { min respectively. Page, } \\
\text { Exponential, Henderson and Pabis, Diffusion Approach were examined for testing the drying } \\
\text { kinetics. Experimental values are in accordance with the expected values resulted Page and } \\
\text { Difussion models of with and without vacuum impregnated pears. Effective diffusion coefficient } \\
\left(D_{\text {eff }}\right) \text { was varying } 2.74 \times 10^{-11} \text { to } 7.31 \times 10^{-11} \mathrm{~m}^{2} / \mathrm{s} . \mathrm{m}^{2} / \mathrm{s} \text { with respect to the drying temperatures. The } \\
\text { activation energy for the non-vacuum impregnated and vacuum impregnated pears was } 32.93 \mathrm{~kJ} / \\
\text { mol and } 24.25 \mathrm{~kJ} / \text { mol, respectively. }\end{array}$ \\
\hline
\end{tabular}

Drying Kinetics

Pear

seymauysal.92@gmail.com

(iD) https://orcid.org/0000-0001-6271-4752

b@ fikret.pazir@gmail.com

Dttps://orcid.org/0000-0003-3997-4892

\section{Introduction}

Drying is one of the most commonly used methods of food preservation; in some cases, the quality of products such as fruits and vegetables can be adversely affected. Such as products which are air-dried at high temperatures, lose their rehydration ability. Undesirable changes can occur in colour, texture and flavor because of the high temperatures. Drying can cause to decrease at some of the nutritional ingredients.

In order to prevent drying damages, different pretreatments are applied such as blanching, immersion, osmotic dehydration and vacuum impregnation (Abano and Sam-Amoah, 2011). One of these pretreatments is the vacuum impregnation which is defined as the osmotic dehydration process under vacuum for a certain period of time. The efficiency of the osmotic dehydration process rises throughout the process (Fito and Chiralt, 2000). Vacuum impregnation is usually used as a pre-treatment of the fruit and vegetables. Because, plant tissues can not reach to water activity level being safe for microbial growth (Us, 2006). Moreover, if vacuum impregnation is combined with air-drying, freezing, freze drying, microwave drying, microwave vacuum drying, vacuum drying it is possible to make a wide range of natural functional products (Betoret et al., 2003; Fito et al., 2001; Hironaka et al., 2011; Schulze, 2012; Maran et al., 2013).

The process parameters must be selected appropriately to determine the effects of vacuum impregnation on the physico-chemical properties and sensory properties of the products. There are many parameters that affect the efficiency of the vacuum impregnation process and the final product quality. The parameters in relation to the raw material can be listed as internal factors ( Type of raw material, the structure of raw metarial and the surface area, thickness, shape of raw metarial) the process parameters during application can be listed as external factors( vacuum Pressure, vacuum time, restoration time after vacuum (impregnation time at atmospheric pressure), the type of solvent used in the impregnation solution, the molecular weight, concentration of the impregnation solution, ratio of impregnation solution to the food, the temperature of the impregnation solution, stirring). 
Drying is also a complicated process which includes both heat and mass transfer (Şahin ve Dinçer, 2005). From the engineering perspective, it is essential to comprehend the control parameters of this complicated process. The mathematical modelling of drying is applied in order to design innovative drying systems, to improve present processes and to control the whole process. Many researchers have developed mathematical models to describe and control drying processes in foodstuffs.

From the point of qualitative and quantitative pomace content of view, pears are considered as the second most important fruits after apple.

The major edible pear species in Turkey is P. communis as well (Öztürk et al., 2009). In this study, the deveci species (Pyrus communis L.), one of the widely grown pear varieties in Turkey, was procured from the local market. The deionized apple juice concentrate was used as the impregnation solution. In order to improve the sensory and quality characteristics of dried pears, it was aimed to impregnate the fruits with their own sugars by using deionized apple juice concentrate instead of sugar derivatives such as sucrose and glucose which are frequently used as impregnation solution during vacuum impregnation process. The deionized apple juice concentrate, consisting of the majority of the sugars was obtained by removing the minerals, phenolic substances and other components as much as possible from the solution.

The aim of this study was to investigate the drying kinetics of vacuum impregnated and non- vacuum impregnated pears. It also intends to test the conformance of mathematical models with the product, to select the model that describes the kinetic behaviour most satisfactorily and to compute the effective moisture diffusivity.

\section{Material and Method}

\section{Material}

The pears (Deveci (Pyrus communis L.)) were purchased from a local market located in İzmir, Turkey and stored $\left(4^{\circ} \mathrm{C}\right.$ and \%80-85 $\left.\mathrm{RH}\right)$ at the Pilot Plant of Ege University Food Engineering Department in İzmir. The raw material to be used in the experiments was sliced at a thickness of $15 \mathrm{~mm}$ after being peeled and the core house was removed. The outer and inner diameters of the pears were measured 65 and $20 \mathrm{~mm}$ respectively. The pears was blanched for inactivation of polyphenol oxidase enzyme in boiling water. The preliminary tests were performed in order to determine the blanching time. The necessary blanching time was assessed as 5 min as a result of these tests. The deionized apple juice concentrate was used impregnation solution and was purchased from a manufacturer in Turkey.

\section{Method}

\section{Vacuum Impregnation Process}

The evacuation of the experimental setup were provided by a vacuum oven (Heraeus, VT 5042, Germany) (Figure 1). The deionized apple juice concentrate was used an impregnation solution. The pears were immersed in beakers containing the impregnation solution before vacuum was applied. The optimum condition for vacuum impregnation process (vacuum pressure (200,350,500 mbar), vacuum time $(15,30,45 \mathrm{~min})$ and concentration $\left(30,40,50^{\circ}\right.$ Brix $)$ was determined by Desirability method in Response Surface Methodology with the preliminary study. The optimum condition of vacuum impregnation was $50^{\circ}$ Brix impregnation solution concentration, 225 mbar vacuum pressure and 45 min vacuum time. The other parameters of vacuum impregnation process were temperature at $35^{\circ} \mathrm{C}$ (Paes et al., 2008), restoration time at $60 \mathrm{~min}$ (Zhao and Xie, 2004) and a ratio of food over solution at (1/5) (w/w) (Erünal, 2010).

\section{Air-Drying Process}

Non-vacuum impregnated (blanched pears) and vacuum impregnated pears was dried at laboratory type tray dryer (Weintek, TURKEY) (Figure 2.). The experiments were conducted in the production facility of Ege University Food Engineering Department. The equipment consists of 10 trays, upper and lower pipes, a broiler, a fan, bottom air suction line and a heater. The trays

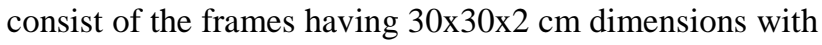
pores of $3 \times 3 \mathrm{~mm}$ made of stainless steel. The air flow was parallel to the direction where the trays are placed. The uniform distribution of air over the trays inside the tray dryer was performed by an engine rotating at $10 \mathrm{rpm}$.
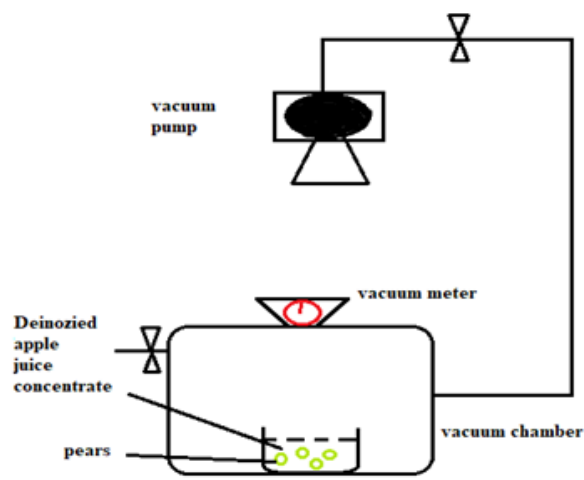

Figure 1. Schematical Diagram Of The Vacuum Impregnation Process

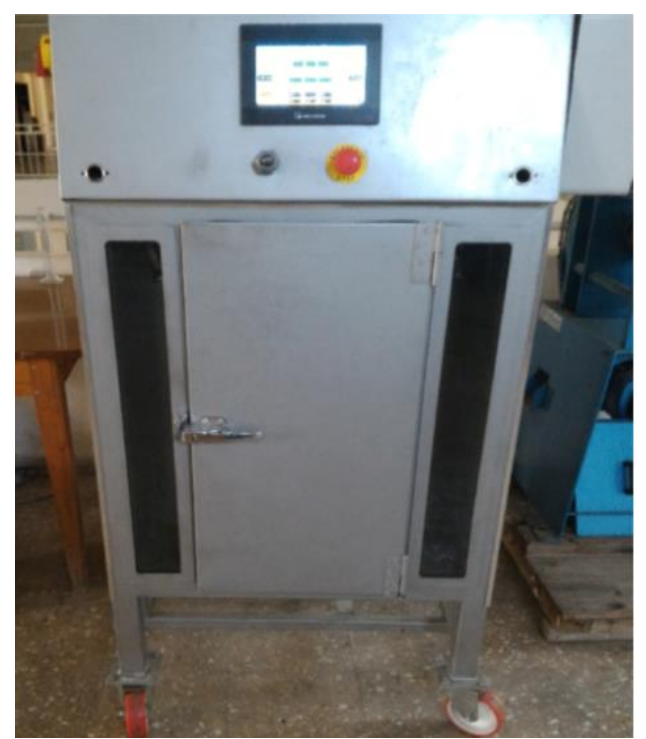

Figure 1 Laboratory Type Tray Dryer (Weintek, TURKEY) 
Drying experiments were performed at different temperatures $\left(55,65\right.$ and $\left.75^{\circ} \mathrm{C}\right)$. The air velocity was $1 \mathrm{~m} / \mathrm{s}$ and was kept constant at the process. The weight of pears $200 \pm 4,12 \mathrm{~g}$ were placed into one tray. The datas were recorded after the temperature reached the experimental condition at the drying process. All the data were monitored 20 minutes intervals automatically by the dryer. The drying was going on the moisture content of the product became $15 \%$.

\section{Moisture Analyses}

The moisture analysis of the pears were carried out in a vacuum oven (WiseVen WOW-30, Germany) at $65^{\circ} \mathrm{C}$. The moisture content of non-vacuum impregnated and vacuum impregnated pears were $83.5 \pm 0.5$ and $\% 71.4 \pm 1.2$ respectively.

\section{Examination of Drying Kinetics}

The most widely used method to measure effective moisture diffusivity is experimentally from drying curves based on the solution of Fick's second law equation. Assuming a constant diffusion coefficient, Fick's equation with one-dimensional diffusion for different geometries slab, cylinder and sphere) can be given as (Srikiatden, 2007)

$$
\left(s \frac{d M}{d t}=D_{\text {eff }}\left(\frac{d^{2} M}{d x^{2}}+\frac{\eta}{r} \frac{d M}{d r}\right) \eta=0\right. \text { for infinite slap }
$$

The assumptions of the diffusion equation for mass transport of initial and boundary conditions:

1. The diffusion coefficient of a pear slices is constant and not a function of moisture concentration.

2. The pear slices is considered isothermal and heat transfer is neglected.

3. The pear slices composition is homogeneous and isotropic.

4. The volume change of the pear slices is negligible during the tempering process.

5. Drying takes place in decreasing speed period.

6 . The shape factor $(\phi)=0.493$ and the calculation is considered as infinite slap due to the lack of similarity to the cylinder, sphere and cube. The geometry of the pear slices is considered as a infinite slap.

7. Mass transfer takes place in one dimension.

The convective boundary conditions of Fick's 2nd law for homogeneous moisture distribution and symmetrical distribution in the center are as follows( Srikiatden, 2007);

$$
\begin{aligned}
& \mathrm{M}(\mathrm{r}, 0)=M_{i}, \mathrm{t}=0 \text { (initial condition) } \\
& \mathrm{M}(0, \mathrm{t})=M_{\infty} \mathrm{r}=r_{0}(\text { at the surface) } \\
& \mathrm{M}(0, \mathrm{t})=M_{\infty} \mathrm{r}=0 \text { (at the center) }
\end{aligned}
$$

Equation 2 was obtained when a solution was made according to these conditions.

$$
\begin{aligned}
& \mathrm{MR}=\frac{M_{0}-M_{\infty}}{M_{t}-M_{\infty}}=\frac{8}{\pi^{2}} \sum_{n=0}^{\infty} \frac{1}{(2 n+1)^{2}} \exp \left[-\frac{(2 n+1)^{2} \pi^{2}}{4 L^{2}} D_{e f f} t\right](2) \\
& \mathrm{MR}: \text { Moisture Ratio, } \\
& \mathrm{M}_{0}: \text { Initial Moisture Content, } \\
& \mathrm{M}_{\mathrm{e}}: \text { Equlibrium Moisture Content, } \\
& \mathrm{M}_{\mathrm{t}} \quad \text { : Moisture Content at t time. }
\end{aligned}
$$

Under the conditions where the relative humidity and ambient temperature inside the tray dryer do not come to a steady state, the following assumption can be made. The final moisture content of the product is not equal to the equilibrium moisture content. Hence, equilibrium moisture content $\left(\mathrm{M}_{\mathrm{e}}\right)$ is negligible.

$$
\mathrm{MR}=\frac{M_{0}}{M_{t}}=\frac{8}{\pi^{2}}\left(e^{\left(\frac{\pi}{2}\right)^{2} N_{F_{i}}}+\frac{1}{9} e^{-9\left(\frac{\pi}{2)}\right)^{2} N_{F_{i}}}+\frac{1}{25} e^{-25\left(\frac{\pi}{2}\right)^{2} N_{F_{i}}}\right)
$$

Terms 2 and 3 of Equation 3 are neglected for longterm drying (Fo>0.2). Equation 3 was rewritten only with first term (Equation 4).

$$
\begin{aligned}
& \mathrm{MR}=\frac{M_{0}}{M_{t}}=\frac{8}{\pi^{2}}\left(\mathrm{e}^{\left(\frac{\pi}{2}\right)^{2} \mathrm{~N}_{\mathrm{F}_{\mathrm{i}}}}\right. \\
& \mathrm{N}_{\mathrm{Fi}}=\mathrm{D}_{\mathrm{eff}} \mathrm{t} / \mathrm{L}^{2} \\
& \mathrm{MR}=\frac{\mathrm{M}_{0}}{\mathrm{M}_{\mathrm{t}}}=\frac{8}{\pi^{2}}\left(\mathrm{e}^{-\left(\frac{\pi}{2}\right)^{2} \mathrm{D}_{\mathrm{eff}} \mathrm{t} / \mathrm{L}^{2}}\right) \\
& \mathrm{N}_{\mathrm{Fi}}: \text { Fick Constant, } \\
& \mathrm{D}_{\mathrm{eff}}: \text { effective diffusion coefficient }\left(\mathrm{m}^{2} / \mathrm{s}\right), \\
& \mathrm{L} \quad: \text { Thickness of product }
\end{aligned}
$$

The conformance of the experimental data with four empirical model (Table 1) was tested by SPSS 20.0 software and conducting non-linear regression analysis. For each experiment, coefficient of determination $\left(\mathrm{R}^{2}\right)$, root of square mean error (RMSE) (Equation 5) and reduced chi-square $\left(\chi^{2}\right)$ (Equation 6) values were computed respectively. The model with the highest value of coefficient of determination $\left(\mathrm{R}^{2}\right)$, and the least RMSE and the least reduced chi-square $(\chi 2)$ values has been determined as the best model for each experiment with the goodness of fit and minimum standard deviation between expected and observed values (Sun et al., 2007; Lahsasni et al., 2004). RMSE $=\left[\frac{1}{N} \sum_{i=1}^{N}\left(M R_{b, i}-M R_{d, i}\right)^{2}\right]^{1 / 2}$

(5)

$$
\chi^{2}=\sum_{i=1}^{N} \frac{\left(M R_{d, i}-M R_{b, i}\right)^{2}}{N-n}
$$

MRd,i i. : Experimental value measured in observation, $\mathrm{MRb}, \mathrm{i}$ i. : Expected value in observation,

$\mathrm{N} \quad$ : Number of observations

$\mathrm{N} \quad$ :The number of the constants in the model.

Calculation of Effective Moisture Diffusivity and Activation Energy

In order to determine the effect of difusion, the difusion that takes place by multi mechanisms simultaneously can be described as one unique term called effective moisture diffusivity $\left(D_{\text {eff }}\right)$. It is a great importance to calculate the $D_{\text {eff }}$ values from the perspective of the drying behaviour and characteristics of the product (Erbay, 2008). The $D_{\text {eff }}$ values were found out by plotting the natural logarithm of the fractional moisture ratio (ln MR) obtained by the observed drying values versus time and slope of this graph gives the $\mathrm{D}_{\text {eff }}$ values (Lomauro et al., 1985, Doymaz et al., 2004). 
In order to evaluate the effect of temperature on the effective moisture diffusivity the Arrhenius equation (Equation 7) can be used (Lopez et al., 2000; Srikiatden and Roberts, 2006).

$$
D_{\text {eff }}=D_{0} \exp \left(-\frac{E_{a}}{R T}\right)
$$

Activation energy (EA) can be calculated by the slope obtained by plotting the graph of natural logarithm of effective moisture diffusivity $\left(\ln \left(D_{\text {eff }}\right)\right)$, versus inversion of temperature $(1 / \mathrm{T})$ in $1 / \mathrm{K}$ units.

Table 1. Drying kinetics models

\begin{tabular}{l|ll}
\hline \multicolumn{1}{c|}{ Model Name } & \multicolumn{1}{|c}{ Model Equation } & $\mathrm{R}$ \\
\hline Page & $\mathrm{MR}=\exp \left(-\mathrm{kt}^{\mathrm{n}}\right)$ & 1 \\
Exponential & $\mathrm{MR}=\exp (-\mathrm{kt})$ & 2 \\
Henderson and Pabis & $\mathrm{MR}=\mathrm{aexp}(-\mathrm{kt})$ & 3 \\
Diffusion Approach & $\mathrm{MR}=\mathrm{aexp}(-\mathrm{kt})+(1-\mathrm{a}) \exp (-\mathrm{kbt})$ & 4 \\
\hline
\end{tabular}

R: References, 1: Uysal et al. (2017), 2: Eren et al. (2008), 3: Koçak et al. (2018), 4: Ertekin and Yaldız (2004)

\section{Results and Discussion}

Pear samples were dried until they reached $15 \%$ moisture content in the tray dryer. The weight of pear samples were measured at $20 \mathrm{~min}$ time intervals automatically by the dryer and the moisture ratio (MR) was calculated according to these datas. The graphs of moisture ratio versus time for non-vacuum impregnated pears and vacuum impregnated pears were shown in Figure 3 and Figure 4, respectively.

When Figure 3 was examined, drying time of nonvacuum impregnated pears at 55,65 and $75^{\circ} \mathrm{C}$ was determined 640, 500 and 340 min respectively. The drying time was decreased when the drying temperature was increased for non-vacuum impregnated pears. Hence, the shortest drying time $(340 \mathrm{~min})$ was occurred at $75^{\circ} \mathrm{C}$.

When Figure 4 was examined, drying time of vacuum impregnated pears at 55,65 and $75^{\circ} \mathrm{C}$ was determined 700 , 540 and $560 \mathrm{~min}$, respectively. The drying time was not linearly changed with the drying temperature for the vacuum impregnated pears. The shortest drying time (540 min) was occurred at $65^{\circ} \mathrm{C}$. As generally known, drying time was affected from drying temperature. However, for the vacuum impregnated pears, external resistance across the drying was high because of the sugar content especially

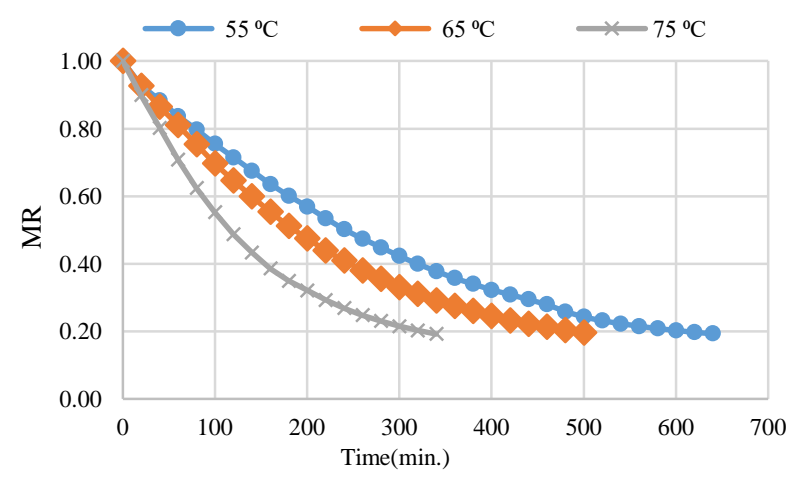

Figure 3. Experimental moisture ratios (MR) of nonvacuum impregnated pears at different drying temperature at high temperatures. Therefore, drying time of vacuum impregnated pears at $75^{\circ} \mathrm{C}$ is higher than that for vacuum impregnated pears at $65^{\circ} \mathrm{C}$.

Drying time of vacuum impregnated pears were higher than non vacuum impregnated pears at constant temperature. Vacuum impregnated pears had higher sugar content than non-vacuum impregnated pears. There were bonds occurred between sugar and water molecules. Therefore, for removing the same amount of water from the pears, the long drying time was needed. Kaya et al. (2016) was determined the total convective dehydration times of osmo-dehidrated carrot samples at $55^{\circ} \mathrm{C}$. The dehydration time was 900 min for osmo-dehidrated carrot samples.

\section{Evaluation of Drying Kinetics}

Examination of drying kinetics were performed according to the $\mathrm{R}^{2}, \chi^{2}$, RMSE values which were given in Table 2. The model with the highest $\mathrm{R}^{2}$ and the lowest $\chi 2$ and RMSE values was selected as the appropriate model. It might be pointed out that two different models (Page and Diffusion Approach) are able to describe the kinetic behaviour of pear samples conveniently.

The Page model was the best fitted model for non vacuum impregnated pearss dried at 55 and $65{ }^{\circ} \mathrm{C}$. The coeficients of determination $\left(\mathrm{R}^{2}\right)$ was 1.00 and 0.998 , the root of square mean error (RMSE) values was 0.0137 and 0.0196 and the reduced chi-square $(\chi 2)$ values were found to be $1.16 \times 10^{-6}$ and 0.0004 for Page model at 55 and $65^{\circ} \mathrm{C}$ respectively. The best fitted model for non-vacuum impregnated pears dried at $75^{\circ} \mathrm{C}$ was Diffusion model. $\mathrm{R}^{2}$, RMSE and $\chi^{2}$ values of Diffusion Model were 0.999, 0,0066 and $5.28 \times 10-5$, respectively.

The appropriate model for vacuum impregnated pears dried at 55 and $65^{\circ} \mathrm{C}$ were Diffusion which had $\mathrm{R}^{2}$ values of 0.999 and 0.995 , RMSE values of 0,0054 and 0.0201 and $\chi 2$ values of $1,297 \times 10^{-5}$ and 0.0004 . The Page model was suitable model for the vacuum impregnated pears dried at $75^{\circ} \mathrm{C}$. The $\mathrm{R}^{2}, \mathrm{RMSE}$ and $\chi^{2}$ values of Page model were $0.998,0.0198$ and 0,0002 respectively. Also, Sahin and Ozturk (2015) were performed vacuum impregnation process before air drying of fig samples at $75^{\circ} \mathrm{C}$. That study was examined ten different drying model. The best fitted model of vacuum impregnated and non vacuum impregnated fig samples was Weibull distribution model and Verma model respectively.

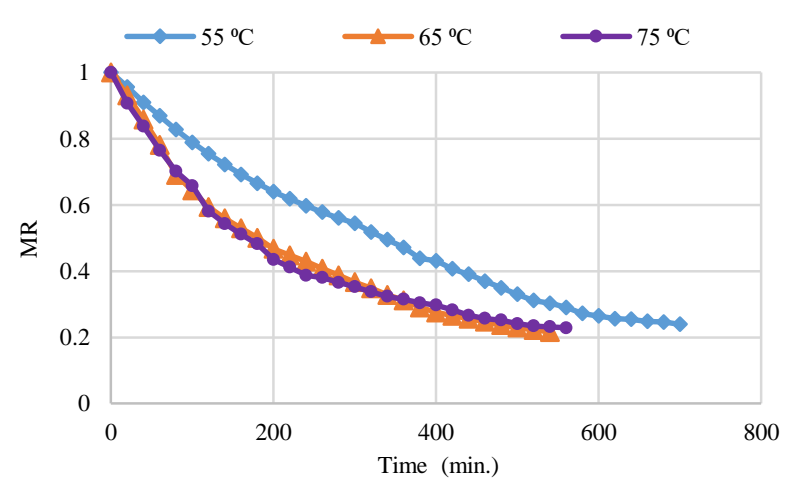

Figure 4. Experimental moisture ratios (MR) of vacuum impregnated pears at different drying temperature 
Table 2. Statistical evaluation of drying models for pears $\left(\mathrm{R}^{2}, x^{2}, \mathrm{RMSE}\right.$ Values)

\begin{tabular}{l|ccccccc}
\hline \multirow{2}{*}{ Model Name } & \multirow{2}{*}{$\begin{array}{c}\text { Drying } \\
\text { Temperature }\left({ }^{\circ} \mathrm{C}\right)\end{array}$} & \multicolumn{2}{c}{ Non-Vacuum Impregnated Pears } & \multicolumn{3}{c}{ Vacuum Impregnated Pears } \\
\cline { 2 - 7 } Page & 55 & 1.000 & 0.0137 & $1.16 \times 10^{-5}$ & 0.981 & 0.199 & 0.0134 \\
& 65 & 0.998 & 0.0196 & 0.0004 & 0.985 & 0.2072 & 0.0259 \\
& 75 & 0.996 & 0.0214 & 0.0005 & 0.998 & 0.0198 & 0.0002 \\
\hline \multirow{3}{*}{ Exponential } & 55 & 0.999 & 0.0221 & $6.72 \times 10^{-5}$ & 0.932 & 0.0537 & 0.0016 \\
& 65 & 0.998 & 0.0421 & 0.0018 & 0.976 & 0.0686 & 0.0038 \\
& 75 & 0.993 & 0.0291 & 0.0009 & 0.836 & 0.0704 & 0.0022 \\
\hline \multirow{2}{*}{ Henderson ve } & 55 & 0.999 & 0.0256 & $7.42 \times 10^{-5}$ & 0.953 & 0.0459 & 0.0005 \\
Pabis & 65 & 0.998 & 0.0431 & 0.0020 & 0.977 & 0.0608 & 0.0031 \\
& 75 & 0.994 & 0.0013 & 0.0013 & 0.922 & 0.0577 & 0.0033 \\
\hline \multirow{3}{*}{ Diffusion } & 55 & 0.999 & 0.0246 & $7.16 \times 10^{-5}$ & 0.999 & 0.0054 & $1.297 \times 10^{-5}$ \\
& 65 & 0.998 & 0.0397 & 0.0017 & 0.995 & 0.0201 & 0.0004 \\
& 75 & 0.999 & 0.0066 & $5.28 \times 10^{-5}$ & 0.986 & 0.1139 & 0.0033 \\
\hline
\end{tabular}

Table 3. Model coefficients at different drying temperatures for pears

\begin{tabular}{l|ccccccccc}
\hline \multirow{2}{*}{ Model Name } & \multirow{2}{*}{$\begin{array}{c}\text { Drying } \\
\text { Temperature }\left({ }^{\circ} \mathrm{C}\right)\end{array}$} & \multicolumn{3}{c}{ Non-Vacuum Impregnated Pears } & \multicolumn{3}{c}{ Vacuum Impregnated Pears } \\
\cline { 3 - 10 } Page & 55 & 0.003 & 0.967 & - & - & 0.005 & 0.741 & - & - \\
& 65 & 0.004 & 0.969 & - & - & 0.010 & 0.871 & - & - \\
& 75 & 0.008 & 0.921 & - & - & 0.027 & 0.607 & - & - \\
\hline \multirow{3}{*}{ Exponential } & 55 & 0.003 & - & - & - & 0.002 & - & - & - \\
& 65 & 0.004 & - & - & - & 0.002 & - & - & - \\
\hline \multirow{2}{*}{ Henderson } & 75 & 0.006 & - & - & - & 0.003 & - & - & - \\
and Pabis & 55 & 0.003 & - & 0.989 & - & 0.002 & - & 0.925 & - \\
& 65 & 0.004 & - & 0.992 & - & 0.002 & - & 0.983 & - \\
& 75 & 0.005 & - & 0.986 & - & 0.003 & - & 0.858 & - \\
\hline \multirow{2}{*}{ Diffusion } & 55 & 0.003 & - & 1.00 & -4.081 & 0.003 & - & 0.944 & -0.664 \\
& 65 & 0.004 & - & 1.274 & 1.000 & 0.003 & - & 0.994 & -1.950 \\
& 75 & 0.006 & - & 0.955 & -1.268 & 0.008 & - & 0.594 & 0.055 \\
\hline
\end{tabular}

Table 4. Effective Diffusion Coefficients of Pears at Different Temperatures

\begin{tabular}{c|cc}
\hline \multirow{2}{*}{ Drying Temperature $\left({ }^{\circ} \mathrm{C}\right)$} & Non-Vacuum Impregnated Pears & Vacuum Impregnated Pears \\
\cline { 2 - 3 } & $\mathrm{D}_{\text {eff }}\left(\mathrm{m}^{2} / \mathrm{s}\right)$ & $\mathrm{D}_{\text {eff }}\left(\mathrm{m}^{2} / \mathrm{s}\right)$ \\
\hline 55 & $3.65 \times 10^{-11}$ & $2.7410^{-11}$ \\
65 & $5.48 \times 10^{-11}$ & $3.6510^{-11}$ \\
75 & $7.31 \times 10^{-11}$ & $4.5710^{-11}$ \\
\hline
\end{tabular}

Model coefficients were determined by using MR values and SPSS 20.0 program for all selected models. Determined model coefficients were given in Table 3. The value of $\mathrm{k}$ in that table represents the drying rate constant. It can be clearly observed that this value is directly proportional to the drying temperature. That is the the higher drying temperature, the greater the $\mathrm{k}$ value. This constant is an indicator of drying rate. The rise in this value is an evidence for the increase in drying rate and the decline in drying time. Similar results were found by Simal et al., (2005) for kiwi fruit. The $\mathrm{k}$ parameter of the model increased with the increase of the drying air temperature of kiwi fruits for the whole range of temperatures studied.

Evaluation of Effective Diffusivity Coefficients and Activation Energy

The effective diffusivity coefficients ( $\left.D_{\text {eff }}\right)$ was computed by plotting experimental drying data in terms of $\ln (\mathrm{MR})$ versus time (Lomauro et al.,1985; Doymaz and Akgün, 2009). The values of effective diffusivity coefficients were given in Table 4 . Range of $D_{\text {eff }}$ values were from $2.74 \times 10^{-11}$ to $7.31 \times 10^{-11} \mathrm{~m}^{2} / \mathrm{s}$. The highest effective moisture diffusivity was obtained by the experiment performed at $75^{\circ} \mathrm{C}$ without vacuum impregnatiom process. It was observed that the effective diffusion coefficient increased as the temperature increased. The effective diffusion coefficient of nonvacuum impregnated pears was found to be larger than the vacuum impregnation pears' one.

$\ln \left(\mathrm{D}_{\text {eff }}\right)-1 / \mathrm{T}$ (absolute temperature in $\mathrm{K}$ ) was plotted and the linearity of Arrhenius equation was shown in Figure 5. and Figure 6. The activation energy for the nonvacuum impregnated pears was $32.93 \mathrm{~kJ} / \mathrm{mol}$ and the activation energy for the pears with vacuum impregnation was calculated as $24.25 \mathrm{~kJ} / \mathrm{mol}$. "Activation energy is an indication of the sensitivity of the diffusion to temperature. The high activation energy value shows that the effective diffusivity is highly sensitive to temperature (KaymakErtekin. 2002). The effective diffusivity of non-vacuum impregnated samples has a higher sensitivity to temperature. These values are in fact consistent with those existing in the literature. 


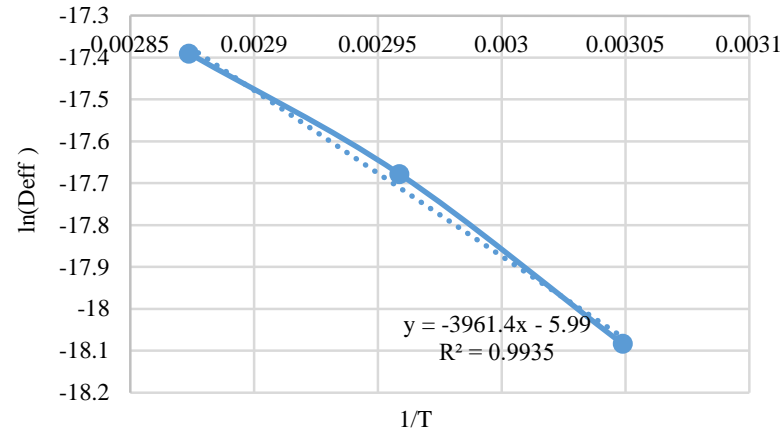

Figure 5. Arrhenius type relationship between effective Diffusivity (Deff ) $\left(\mathrm{m}^{2} / \mathrm{s}\right)$ and Temperature $(1 / \mathrm{K})$ in nonvacuum impregnated pears

Ramirez et al. (2011) were found that the effect of vacuum impregnation on the effective diffusion coefficient was not significant and they found that the control group samples and the effective diffusion coefficient had similar values. Sahin and Ozturk (2016) were found effective diffusivity coefficient in between $2.75 \times 10^{-10}$ and $10.25 \times 10^{-10}$. The activation energy for the non-vacuum impregnated pears was $34.68(\mathrm{~kJ} / \mathrm{mol})$ and the activation energy for the pears with vacuum impregnation was calculated as $50.26 \mathrm{~kJ} / \mathrm{mol}$.

\section{Conclusion}

Pear samples was dried at constant air velocity of $1 \mathrm{~m} / \mathrm{s}$, different temperatures 55, 65 and $75^{\circ} \mathrm{C}$ and with and without vacuum impregnation until moisture content was reduced to under \%15. Drying time of non-vacuum impregnated pears was determined as 640, 500 and 340 min and that for vacuum impregnated pears was determined as 700, 540 and 560 min respectively. It may be claimed that vacuum impregnation process had significant effect on drying times. Drying time of vacuum impregnated pears were higher than non vacuum impregnated pears. For the vacuum impregnated samples, external resistance across the drying were high because of the sugar content, especially at high temperatures. In accordance with the data related to drying, four kinetic models within drying model concept were evaluated. Experimental values were in accordance with the expected values resulted two empirical models (Page and Difussion) and hence the kinetic behaviour of with and without vacuum impregnated pears. The effective moisture difusivity was computed and it was determined that effective moisture diffusivity was directly proportional to drying temperature. Activation energy was also calculated $32.93 \mathrm{~kJ} / \mathrm{mol}$ and $24.25 \mathrm{~kJ} / \mathrm{mol}$ by the Arrhenius theory.

\section{Acknowledgement}

The authors wish to thank Ege University Scientific Research Project for financially supporting this study under Project Number 18-TKMYO-001.

\section{References}

Betoret N, Puente L, Diaz MJ, Pagan MJ, Garcia MJ, Gras ML, Marto J, Fito P. 2003. Development of probiotic-enriched dried fruits by vacuum impregnation. Journal of Food Engineering. 56(2-3): 273-277

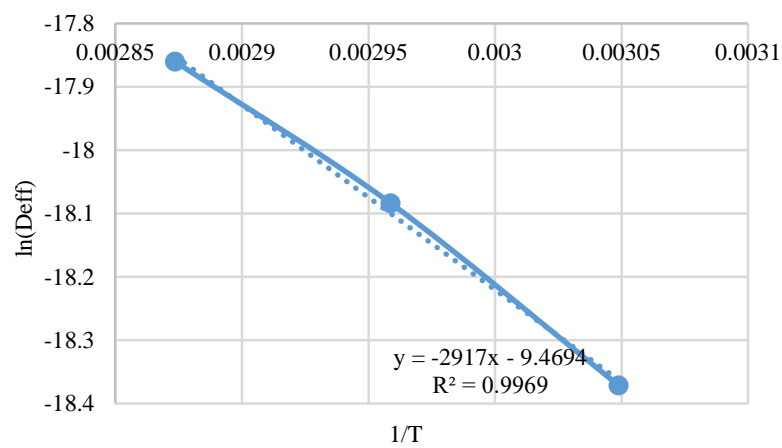

Figure 6. Arrhenius type relationship between effective Diffusivity (Deff ) $\left(\mathrm{m}^{2} / \mathrm{s}\right)$ and Temperature $(1 / \mathrm{K})$ in vacuum impregnated pears

Doymaz I, Akgun NA. 2009. Study of Thin-Layer Drying of Grape Wastes. Chemical Engineering Communications., 196(7): 890-900 DOI: 10.1080/00986440802668422

Doymaz I, Gorel O, Akgun NA. 2004. Drying characteristics of the solid byproduct of olive oil extraction. Biosystem Engineering., 88:213-219. DOI:10.1016/j.biosystemseng. 2004.03.003

Erbay Z. 2008. The Investigation of Modelling, Optimization and Exergetic Analysis of Drying of Olive Leaves. MSc, Ege University, İzmir, Turkey.

Eren İ, Y1ldı-Turp G, Kaymak-Ertekin F, Serdaroğlu M. 2008. The Effect of External Mass Transfer Resistance during Drying of Fermented Sausage. Drying Technology., 26:1543-1555. DOI: 10.1080/07373930802466724.

Ertekin C, Yaldiz O. 2004. Drying of eggplant and selection of a suitable thin layer drying model. Journal of Food Engineering., 63: 349-359. DOI: 10.1016/j.jfoodeng. 2003.08.007.

Erünal S. 2010. Investigation of osmotic dehydration parameters of plum (prunus domestica) and theirs' effect on drying, Msc Thesis, Afyon Kocatepe University, Turkey

Faustino JMF, Barroca MJ, Guine' RPF. 2007. Study of the drying kinetics of green bell pepper and chemical characterization. Food Bioproducts Processing., 85(C3): 163-170. DOI:10.1205/fbp07009 0960-3085/07/ \$30.00 + 0.00.

Fito P, Chiralt A, Barat JM, Andres A, Martinez-Monzo J, Martinez-Navarrete N.2001. Vacuum impregnation for development of new dehydrated products. Journal of Food Engineering., 49: 297-302.

Hironaka K, Kikuchi M, Koaze H, Sato T, Kojima M, Yamamoto K, Yasuda K, Mori M, Tsuda S. 2011. Ascorbic acid enrichment of whole potato tuber by vacuum-impregnation. Food Chemistry., 127(3):1114-1118 DOI: $10.1016 / j$. foodchem.2011.01.111.

Kaya A, Aydin O, Kolayli S. 2016. Influence of Osmotic Dehydration On Dryıng Kinetıcs Of Carrot. Isi Bilimi ve Teknigi Dergisi/Journal of Thermal Science \& Technology., 36(2): 155-162.

Kaymak-Ertekin F.2002. Drying and rehydrating kinetics of green and red peppers. Journal of Food Science.,67(1):168175. DOI: 10.1111/j.1365-2621.2002.tb11378.x

Koçak E, Uysal Ş, Turan F, Ova G, Pazır F.2018. Examination Of Drying Kinetics For Red Grape Pomace. Journal of Engineering Sciences and Design.6(2):316 - 323. DOI: 10.21923/jesd.397342

Lahsasni S, Kouhila M, Mahrouz M, Idlimam A, Jamali A. 2004. Thin layer convective solar drying and mathematical modelling of prickly pear peel (Opuntina ficus indica). Energy.,29:211-224. DOI: 10.1016/j.energy.2003.08.009

Lomauro CJ, Bakshi AS, Labuza T P. 1985. Moisture transfer properties of dry and semimoist foods, Journal of Food Science.50:397-400. DOI: 10.1111/j.1365-2621.1985. tb13411.x 
Lopez A, Iguaz A, Esnoz A, Virseda P. 2000. Thin layer drying behaviour of vegetable wastes from wholesale market. Drying Technology, 18:995-1006. DOI: 10.1080/ 07373930008917749

Maran JP, Sivakumar V, Thirugnanasambandham K, Sridhar R. 2013. Artificial neural network and response surface methodology modeling in mass transfer parameters predictions during osmotic dehydration of Carica papaya L. Alexandria Engineering Journal., 52(3): 507 - 516. DOI: 10.1016/j.aej.2013.06.007

Ozturk I, Ercisli S, Kalkan F, and Demir, B. 2009. Some chemical and physico-mechanical properties of pear cultivars. African journal of Biotechnology., 8(4): 687-693.

Paes SS, Stringari GB, Laurindo JB. 2008. Effect of Vacuum Impregnation Temperature on the Mechanical Properties and Osmotic Dehydration Parameters of Apples. Brazılian Archives of Biology And Technology., 51(4):799-806. DOI: 10.1590/S1516-89132008000400018

Ramírez C, Troncoso E, Muñoz J, Aguilera JM. 2011. Microstructure analysis on pre-treated apple slices and its effect on water release during air drying. Journal of Food Engineering., 106:253-261 DOI: 10.1016/j.jfoodeng. 2011.05.020

Sarsavadia PN, Sawhney RL, Pangavhane DR, Singh S P. 1999. Drying Behaviour of Brined Onion Slices. Journal of Food Engineering., 40: 219-226. DOI: 10.1016/S0260-8774(99) 00058-8

Schulze B, Peth S, Hubbermann EM, Schwarz K. 2012. The influence of vacuum impregnation on the fortification of apple parenchyma with quercetin derivatives in combination with pore structures Xray analysis. Journal of Food Engineering., 109(3):380 - 387. DOI: 10.1016/j. jfoodeng.2011.11.015
Simal S, Femenia A, Garau MC, Rossello C. 2005. Use of exponential, Page's and diffusional models to simulate the drying kinetics of kiwi fruit, Journal of Food Engineering 66: 323-328 DOI: 10.1016/j.jfoodeng.2004.03.025

Singh RP, Heldman D.2015. Introduction to Food Engineering., Elsevier Inc.New York.USA. ISBN: 9780123985309

Srikiatden J, Roberts JS. 2006. Measuring moisture diffusivity of potato and carrot (core and cortex) during convective hot air and isothermal drying, Journal of Food Engineering, 49: 143152. DOI: 10.1016/j.jfoodeng.2005.02.026

Srikiatden J. 2007. Moısture Transfer in Solid Food Materıals: A Review of Mechanisms, Models, And Measurements. International Journal of Food Properties. 10:739-777. DOI: 10.1080/10942910601161672

Sun J, Hu X, Zhao G, Wu J, Wang Z, Chen F, Liao X. 2007. Characteristics of Thin-Layer İnfrared Drying of Apple Pomace with And Without Hot Air Pre-Drying. Food Sci. Technol. Int. 13: 91-97. DOI: 10.1177/1082013207078525

Şahin AZ, Dinçer I. 2005. Prediction of drying times for irregularshaped multi-dimensional moist solids. Journal of Food Engineering., 71:119-126. DOI: 10.1016/j. jfoodeng.2004.10.024

Şahin U, Öztürk HK. 2016. Experımental Investıgatıon of Dryıng Kinetics of Pretreated and Non-Pretreated Figs (Ficus Carica L.). Mugla Journal of Science and Technology., 2(1): 20-26. DOI: $10.22531 /$ muglajsci.269967

Us F. 2006. Ozmotik Kurutma, Türkiye 9. Gida Kongresi, Bolu.

Uysal Ş, Turan F, Koçak E, Ova G, Pazır F. 2017. Inspection of the Drying Kinetics for Spaghetti Squash (Cucurbita Pepo L.). Polish Journal of Food Engineering., 3(4):31-37. Zhao Y, Xie J, 2004, Practical applications of vacuum impregnation in fruit and vegetable processing. Trends in Food Science \& Technology., 15(9):434-451DOI:10.1016/j.tifs.2004.01.008 